\title{
A GENEALOGIA DOS DIREITOS HUMANOS E SUA EVOLUÇÃO EPISTEMOLÓGICA. UMA ANÁLISE CRÍTICA, À LUZ DA PARTICIPAÇÃO SOCIAL DA MULHER NA HUMANIDADE.
}

Otavio Ernesto Marchesini ${ }^{1}$

\section{RESUMO}

Decorridos 32 (trinta e dois) anos do Ano Internacional da Mulher, cabe seja feita uma reflexão crítica quanto ao papel assumido pela mulher nas relações sociais (consideradas como tais em uma macro e plúrima acepção), enquanto componente da humanidade, e os respectivos desdobramentos desta inserção na construção da sociedade que ora se verifica existente. A presente proposta é levada a efeito, através deste artigo, valendo-se, para tanto, de um cotejo analítico com a genealogia e evolução epistemológica do Direito, em face dos Direitos Humanos, considerando-se o paulatino e gradual evolver da condição feminina.

\section{ABSTRACT}

As 32 (thirty two) years had already passed since the advent of the Woman International Year, a critical reflection should be done about the actual role assumed by the woman in the social relationships (considered as such in a plural and macro assumption), as a component of the humanity, as well as the reciprocals effects of such an insertion in the construction of the current society. The actual study is proposed, within this article, using, for such, an analytical comparison with the genealogy and epistemological evolution of the Law, in front of the Human Rights, considering the slowly and gradual evolution of the woman condition.

\footnotetext{
${ }^{1}$ Advogado; professor de Direito Internacional dos Direitos Humanos na Universidade Tuiuti do Paraná.
}

Revista Brasileira de Direito Internacional, Curitiba, v.6, n.6, jul./dez.2007 
PALAVRAS-CHAVE: Epistemologia do Direito - Direitos Humanos - Mulher.

KEY-WORDS: Epistemology of Law - Human Rights - Woman. 


\section{INTRODUÇÃO}

Há 32 (trinta e dois) anos, a Organização das Nações Unidas - ONU entendeu por exortar à sociedade internacional a realização de uma reflexão acerca da causa feminina, fazendo, pois, por cunhar e referendar tal momento como o Ano Internacional da Mulher²; concedendo, a partir de então, lastro de oficialidade à conhecida comemoração anual do dia 08 de março ${ }^{3}$. Decorridas mais de três décadas, imagina-se tenha sido possível o engendrar de uma balzaquiana ${ }^{4}$ maturidade quanto ao tema, passível, por corolário, de dar ensejo

\footnotetext{
${ }^{2}$ Em 09 de dezembro de 1974, a ONU, através de sua Assembléia Geral, aprovou a Resolução n.. 3275, proclamando o ano de 1975 como o Ano Internacional da Mulher, fazendo ressaltar a preocupação das Nações Unidas quanto à promoção da igualdade entre homens e mulheres e a necessidade de uma maior integração feminina no desenvolvimento econômico, social e cultural em esferas nacional, regional e internacional. Além disso, rendeu homenagens e reconhecimento à participação feminina no processo de construção de um desenvolvimento econômico cooperativo entre as diversas nações do globo terrestre, destacando o importante papel da mulher como agente edificante de uma paz mundial. Disponível em: http://daccessdds.un.org/doc/RESOLUTION/GEN/NR0/743/54/IMG/NR074354.pdf?OpenEleme nt. Acesso em 30 de outubro de 2007.

${ }^{3}$ Colhe-se no sítio eletrônico da Prefeitura Municipal de São Paulo (SP), a seguinte informação: "Oficializado pela Organização das Nações Unidas (ONU) em 1975, existem duas versões para a escolha do dia 8 de março como Dia Internacional da Mulher. A mais conhecida conta que a data foi escolhida em homenagem a 130 operárias de uma tecelagem de Nova York, nos Estados Unidos, assassinadas por patrões e policiais, em 8 de março de 1857. Elas estariam em greve reivindicando a redução da jornada diária de trabalho de 14 para 12 horas e o direito à licença-maternidade. Reprimidas pela polícia, as trabalhadoras teriam se refugiado na fábrica, cujas portas teriam sido fechadas e o prédio incendiado. Pela segunda versão, a data de 8 de março foi escolhida em comemoração da manifestação realizada pelas trabalhadoras russas no dia 23 de fevereiro de 1917 protestando, sob o lema de "Pão e Paz", contra a fome e a participação da Rússia na Primeira Guerra Mundial. O protesto das mulheres russas não tinha o apoio sequer do Partido Bolchevique - nome do Partido Comunista na época -, mas acabou sendo o estopim da chamada "Revolução de Fevereiro" que, cinco dias depois, provocou a renúncia do czar Nicolau II, determinando o fim da monarquia, o que levaria à tomada do poder pelos comunistas, oito meses depois, na chamada "Revolução de Outubro".". Disponível em: http://www.prefeitura.sp.gov.br/portal/a cidade/noticias/index.php?p=1195. Acessado em 30 de outubro de 2007.

${ }^{4}$ Honoré de Balzac (1799-1850), romancista francês que se notabilizou pela obra $A$ Mulher de Trinta Anos. Segundo o crítico literário Claudinei Vieira: "Esta é, sem dúvida, sua obra mais famosa. Impregnou tanto o imaginário ocidental que muitas pessoas que nunca sequer ouviram falar do escritor francês e nem tem (sic) idéia de sua procedência, conhecem a expressão "mulher balzaquiana". O choque provocado em sua primeira publicação foi bem considerável. Pela primeira vez, um escritor valorizava os pensamentos e desejos de mulheres maduras, prestava atenção em suas angústias, reinvidicava ( $\mathrm{sic}$ ) o direito delas serem felizes, bonitas e sensuais e discutia de maneira franca e objetiva os problemas íntimos de casamentos fracassados. Foi um sucesso mesclado com escândalo e comoção social, cujos reflexos chegam até os dias de hoje." Disponível em http://igeducacao.ig.com.br/igler/materias/207501208000/207784/207784 1.html. Acesso em 30 de outubro de 2007.
} 
a uma reflexão crítica no que diz respeito à evolução da mulher em sua ativa participação no cerne da sociedade, com assunção de responsabilidades que historicamente se lhe eram estranhas e as conseqüências deste buscado evolver emancipatório.

Partindo deste ponto perspectivo, a proposta metodológica é trazer-se à ilação uma comparação entre o desenvolvimento histórico do Direito, à vista do ramo dos Direitos Humanos, desde seus rincões, na Antigüidade, até o momento presente - com as diversas rupturas epistêmicas verificadas -, e a atuação da mulher em variadas culturas, à guisa de multiplicidades espaçotemporais do viver humano, captando, do confronto analítico, alterações sociais, não só no âmbito do saber jurídico, mas da própria condição feminina. Munidos destas referências, crê-se, possamos manejar elementos para a análise reflexiva quanto à possibilidade, alcance e significação de uma emancipação da mulher, notadamente no compreender de um mundo contemporâneo.

Não se olvida que a lenta e sistemática edificação de um Direito Internacional dos Direitos Humanos, voltado à proteção de seres especialmente passíveis de uma tutela específica ${ }^{5}$, é focada, sobremaneira, nas mulheres, porque, mais que à evidência, o gênero feminino demanda uma proteção tal, justificada em razão de todos os abusos e martírios a que se sujeitou - e continua se sujeitando no transcurso do caminhar da humanidade -, fruto discriminatório de padrões limitativos estabelecidos por diversos grupamentos sociais, mas, principalmente, decorrente de um abuso do poder vertido nas esferas dominantes dos agregados humanos, que levou - e leva à condenável prática de agressões físicas, morais e psicológicas, as quais repercutem e se espraiam para searas além do âmbito doméstico, fomentando, em resposta, uma necessária responsabilidade, no sentido de que essas agressões sejam repugnadas e, quiçá, suplantadas em um porvir que, oxalá,

\footnotetext{
${ }^{5}$ Flávia Piovesan menciona: "O advento da International Bill of Rights, como já visto, constitui o marco do processo de proteção internacional dos direitos humanos. A partir dela, inúmeras outras Declarações e Convenções foram elaboradas, algumas sobre novos direitos, outras relativas a determinadas violações, outras, ainda, para tratar de determinados grupos caracterizados como vulneráveis". (Flávia Piovesan, Direitos Humanos e o Direito Constitucional Internacional, Max Limonad, São Paulo, 2002, p. 187).
}

Revista Brasileira de Direito Internacional, Curitiba, v.6, n.6, jul./dez.2007 
esteja por chegar em breve. A par desta questão - sem que dela se esteja alienado -, o que se propõe, todavia, é uma reflexão quanto à efetivação da emancipação da mulher, estabelecendo aqui uma crítica no que diz respeito à respectiva factibilidade e repercussões contingenciais.

Sucede que para além da notória vitimização feminina, a codificação e universalização dos Direitos Humanos, enquanto mote protetivo da mulher, desencadeia conseqüências oblíquas no viver e no conviver social (seja em âmbito nacional, regional e mesmo mundial), que se nos fazem indagar quanto à hipotética existência de atribuições a serem desempenhadas por mulheres e homens, conclamando, no mais, uma compreensão acerca do significado da própria existência e possíveis distinções atributivas a cada qual dos gêneros humanos.

Não há negar quanto às diferenças fisiológicas ${ }^{6}$ e anatômicas entre homens e mulheres - diferenças, aliás, que possibilitam a perpetuação da espécie -, o que nos leva à inefável conclusão de que, faticamente, há distinções; conquanto, juridicamente, esteja-se por construir uma consciência universal de ausências distintivas. Esta louvável senda de proteção, apesar de objetivar atingir êxitos que libertem a humanidade de recalcitrantes sofrimentos e confiram uma real dignidade à pessoa humana, em todas as dimensões em que esta afirmação possa eclodir, pende premida por periclitante confusão a se disseminar entre os Homens (espécie), engastando uma compreensão quanto ao sentido de ser e existir, ex vi das condições igualitárias e dessemelhanças físicas de mulheres e homens (gênero).

De se questionar, a propósito, se aludida conseqüência reflexa decorre da construção deste especial Direito Internacional dos Direitos Humanos, direcionado à proteção das mulheres, ou, antes ao contrário, é resultante de um fluxo libertatório feminino, que passa a ganhar eco no Direito Internacional.

Apoiada na filosofia arendtiana, PIOVESAN exara entendimento quanto à construção histórica dos Direitos Humanos, asseverando:

\footnotetext{
${ }^{6}$ A palavra fisiologia é composta pelos vocábulos gregos physis (natureza) e logos (palavra ou estudo). Ramo da Biologia que se ocupa do estudo das múltiplas funções mecânicas, físicas e bioquímicas dos seres vivos; na área médica, dentre outros objetivos, volta-se à compreensão dos fatores hormonais que acometem, de forma própria e diferenciada, homens e mulheres.
}

Revista Brasileira de Direito Internacional, Curitiba, v.6, n.6, jul./dez.2007 
os direitos humanos não são um dado, mas um construído, uma invenção humana, em constante processo de construção e reconstrução. $^{7}$

Diante desta celeuma, o discorrer do presente artigo se dá no segmentar de três aportes históricos, com a respectiva exposição comparativa para a seara evolutiva dos Direitos Humanos e da mulher no âmbito da vida em sociedade, culminando-se com algumas considerações finais, a seguir escandidas.

${ }^{7}$ PIOVESAN, Flávia. Direitos Humanos e o Direito Constitucional Internacional, Max Limonad, São Paulo, 2002, p. 123-124.

Revista Brasileira de Direito Internacional, Curitiba, v.6, n.6, jul./dez.2007 


\section{A EPISTEME ${ }^{8}$ JURÍDICA DA ANTIGÜIDADE. PERSPECTIVAS GENEALÓGICAS DOS DIREITOS HUMANOS E A CONDIÇÃO FEMININA ENTRE OS ANTIGOS}

É possível construir-se uma ilação acerca da Ciência Jurídica voltando os olhos para o passado e buscando uma compreensão acerca do modo de interpretação, adoção e utilização do Direito por todos aqueles que nos precedem. Nesta toada, e dentro do triplo recorte histórico proposto, o exórdio enseja um sentir do momento que se costuma denominar Antigüidade, levando, via de conseqüência, nossa reflexão aos mundos da magna Grécia e da augusta Roma, em suas respectivas inferências jurídicas.

Uma breve ressalva, no entanto, faz-se jacente e não pode passar in albis: ao se reportar àquelas priscas eras, não podemos olvidar de todo um construído oriental, não há como se esquecer do grande legado produzido por civilizações tais como àquelas da China de Lao Tze (século VI ou IV a.C.) e Confúcio (551 - 479 a.C.), da Índia dos Vedas ${ }^{9}$ e dos Puranas ${ }^{10}$, tampouco do Egito ou da Pérsia, que, dada a sofisticação de seus tecidos sociais, comportam contribuições várias à experiência humana.

Ocorre que a construção da História do Direito se produz com um aporte perspectivo ocidental eurocêntrico, reportando à Antigüidade os momentos que se perfazem no mundo greco-romano, notadamente porque os grupamentos humanos orientais ainda estão mais em uma esfera de instigação do imaginário coletivo do que em um patamar propício ao desvelar racional de uma efetiva sapiência alhures vivenciada ${ }^{11}$, ao menos no que toca àquelas

\footnotetext{
${ }^{8}$ No verbete epistemologia jurídica, esclarece, Nelson Saldanha: "Epistemologia é um termo que tem sido usado em acepções algo diferentes, apesar de sua grande importância filosófica, senão por ela mesma. Vindo de epistème, que em Platão indicava o conhecimento fundado por oposição a doxa, mera opinião, o termo veio a significar principalmente a teoria das ciências (ou, complementarmente, a classificação das ciências), in Dicionário de Filosofia do Direito, Renovar, Rio de Janeiro, 2006, p. 268.

${ }^{9}$ Série de escritos sagrados, vertidos em sânscrito, que dão nascedouro ao Hinduismo, cuja origem se perde na noite dos tempos.

10 Termo sânscrito que se reporta a uma dupla significação: antigüidade e completude. Retrata uma série de escritos afetos à tradicional cultura indiana, com teor destinado àqueles que não podiam acessar aos Vedas.

${ }_{11}$ Exceção à presente assertiva diz respeito ao antigo Egito, eis que, além de mero exercício para o fustigar de uma vã curiosidade, há um ramo específico da ciência - a Egiptologia - que teve seu adventício propiciado como conseqüência das campanhas de Napoleão, com achados
}

Revista Brasileira de Direito Internacional, Curitiba, v.6, n.6, jul./dez.2007 
áreas que, a partir da modernidade, fomentaram a especialização maximizada e fragmentada dos saberes nas ciências (desembocando, inclusive, na Ciência Jurídica).

De qualquer modo, como o presente texto é aduzido em uma análise comparativa da evolução epistemológica do Direito em face da condição social feminina ao longo do tempo, tem-se por valiosa a menção daquelas civilizações outras, que surgem como um manancial analítico das respectivas realidades outrora lá verificadas, ao que se procede, articuladamente, na seqüência.

\subsection{A EPISTEME JURÍDICA COSMOLÓGICA}

O pensamento grego se inicia através de uma interessante dicotomia entre KAOS e KOSMOS, sugerindo, o primeiro termo, um vazio anterior a qualquer existência, um algo incondicionado e atemporal, tendente a ensejar idéias afetas à ontologia filosófica, à essência metafísica de toda manifestação, ao nôumeno aludido por Immanuel Kant ${ }^{12}$. Pois bem, deste $\mathrm{KAOS}^{13}$ exsurge uma contraparte cósmica (ou o KOSMOS grego), a manifestação do

arqueológicos e posterior decifração de hieróglifos por Jean-François Champollion (1790 1832).

${ }^{12}$ Dentro de seu sistema do conhecimento, Immanuel Kant (1724-1804) responde aos céticos quanto à possibilidade de um conhecimento apodítico, ao tempo em que critica os dogmáticos, limitando o campo da razão, circunscrevendo-o no âmbito do racional. Discorre Kant, aliás, que a razão só não é digna porque é equivocadamente utilizada, de modo dogmático, em campos onde não pode operar, no orbe de uma metafísica, para além dos lindes da própria racionalidade. Segundo Kant, a razão traz o conhecimento apodítico, mas apenas no campo do fenômeno. Na metafísica (ou, como denominado, no campo do nôumeno), a razão atua pensando, mas não produz o conhecimento apodítico naquela esfera. Veja-se a exposição trazida por MORRISON, quanto a este particular: "Não podemos alcançar o mundo "puro" e apreender as coisas como elas são em si mesmas independentemente das categorias da mente; contudo, podemos ter consciência da natureza limitativa dessas categorias, e então podemos, significativamente, conceber os conceitos de realidade e conhecimento para além do entendimento humano. Àquilo que, de um lado, é tornado compreensível através das categorias, Kant chama de mundo "dos fenômenos"; ao que se encontra do outro lado, chamada de nôumenos. Desse modo, o resultado empirista de Hume, por meio do qual os conceitos que fornecem base epistemológica derivam, em última instância, do costume da reiterada associação na experiência, é transformado é uma sólida objetividade que provê uma base legítima. Como conseqüência, porém, o mundo se divide naquilo a cujo conhecimento podemos chegar e naquilo que não poderemos nunca conhecer". MORRISON, Wayne. Filosofia do Direito. Dos gregos ao pós-modernismo. São Paulo: Martins Fontes, 2006, p. 162

${ }^{13}$ Não se dê eivas à preambular e superficial associação de idéias no sentido de que KAOS teria por significado desordem, quando, diversamente, significa uma ausência de ordem.

Revista Brasileira de Direito Internacional, Curitiba, v.6, n.6, jul./dez.2007 
imanifesto, o ser do não $\operatorname{ser}^{14}$, traduzindo e retratando o todo fenomenológico constrito no âmbito perceptível sensorial do homem, nas esferas do tempo e do espaço.

Circunscrito ao KOSMOS, o Homem (espécie) percebe toda uma ordem, uma beleza, uma harmonia e, uma justiça, que evola e se manifesta na Natureza (physis), retratando o que é bom, construindo a idéia de um ALGO ou de um SER independente do próprio Homem. A partir deste momento, a epistemologia finca raízes na premissa de que a Verdade independe do Homem e está no Cosmo, dando-se ensejo, pois, ao que hoje se tem como perspectiva cosmológica.

Em senda jurídica, este paradigma cosmológico abre veredas para a criação da Escola do Direito Natura ${ }^{15}$, contendo, em si, traços indeléveis, tais como a crença em um elemento independente do Homem e a existência de leis cósmicas, que, assim o sendo, são universais e eternas; leis estas, detectáveis na Natureza. Assim é que, buscando reverberar a ordem, a beleza e a harmonia verificada na Natureza, o Homem grego almeja a virtude e tenta repercutir as mesmas leis cósmicas naturais em seu viver social e no seu sobreviver individual, edificando, respectivamente, um senso ético e moral que o leva à busca efetiva da Justiça na aplicação do Direito. A Justiça, aliás, é considerada virtude cardeal, a ser alcançada por cada grego em vida, como expressão de sua nobreza e altruísmo no viver, com um quê de autosuperação ${ }^{16}$. O microcosmo (o Homem), deve ser a repetição do macrocosmo.

Depositários de todo um saber grego, os romanos não só o implementaram, como o pigmentaram com uma verve própria, algo pragmática; redundando, do amálgama, a preciosa cultura helênica ${ }^{17}$, que hoje se nos apresenta, levada a efeito, peculiar e profundamente, senão em outras áreas,

\footnotetext{
${ }^{14}$ Deveras interessante trazer-se à lembrança a famosa e nevrálgica questão existencial hamletiana, pontuada por Willian Shakespeare (1564-1616): Ser ou não ser: Eis a questão!

${ }^{15}$ Questões de âmbito jurídico podem ser constatadas no mundo grego a partir do século VIII a.C., através da literatura, notadamente em face da tragédia de Sófocles (496-405 a.C.), Antígona, na qual se abrem, entre outros, debates quanto ao prevalecimento do Direito Natural diante das determinações temporais do governante.

${ }^{16}$ Em Assim Falou Zaratustra, o filósofo alemão Friedrich Nietzsche (1844-1900) aventa a possibilidade do homem se transformar em um super-homem, transcendendo às amarras de suas limitadas condições.

${ }_{17}$ Entre os séculos I e II d.C., a Grécia é invadida pelos romanos, surgindo, doravante o helenismo, que se trata de um hibridismo greco-romano.
}

Revista Brasileira de Direito Internacional, Curitiba, v.6, n.6, jul./dez.2007 
no campo do Direito. Sem se afastar do mesmo paradigma cosmológico - dado que inseridos na Antigüidade Clássica - os romanos dão vazão ao Direito Natural, porém o fazem obliterando a abstração da Justiça na consecução de uma Lei, que mesmo traduzida pelo Homem, expressa os valores da beleza, harmonia e ordem universais e naturais. Há, aqui, uma importante conversão (sem necessária subversão ou corrupção) de jus em lex ${ }^{18}$. Para além disto, o manejo do Direito entre os romanos levou à paulatina construção de instituições burocratizadas, no que se refere ao trato das questões jurídicas, pavimentando terreno para o surgimento dos juristas.

O dinamismo do Direito Romano, com todo o prévio aporte grego, representa uma invulgar contribuição à humanidade, cujos efeitos se espalham e se fazem perceber até o presente momento, permeando, inclusive, uma tradição jurídica brasileira.

Bem longe de pretender um aprofundar do presente tópico, o que não se faz possível no momento presente, um perfunctório mencionar da episteme jurídica da Antigüidade ora é apresentado, em linhas gerais, a fim de situar a evolução do Direito, em sua gênese ocidental.

\subsection{GENEALOGIA DOS DIREITOS HUMANOS}

A rigor, não há como se falar, tecnicamente, na existência de Direitos Humanos antes da modernidade, porquanto a subjetividade (marca e tônica da episteme moderna) somente passe a ser verificada a partir desta secção histórica. Ora, estando alheio à subjetividade, o Direito não pode ser voltado e focado em um sujeito de direito por si, senão e tão somente ejetado para determinadas classes, à guisa de algumas condições, que são todas consectárias daquele paradigma cosmológico, o qual, lembre-se, independe do Homem (espécie). Asseverando-se de forma diversa, tanto na Antigüidade, como na Idade Média, não havia espaço para a construção e verificação

\footnotetext{
${ }^{18}$ Inobstante inescondível alteração da filosofia grega clássica, entre os romanos pontificavam ilustres juristas, que não olvidaram à constante busca da virtude e da justiça, como, Marco Túlio Cícero (106-43 a.C.), por exemplo.
}

Revista Brasileira de Direito Internacional, Curitiba, v.6, n.6, jul./dez.2007 
aplicativa de Direitos Humanos porque o Homem, àqueles tempos, ainda não tinha construído sua individualidade.

Evidentemente, todo Homem antigo e medieval possuía um composto corporal físico que se the conferia uma individuação, porém, mais além disso, a idéia psíquica-racional desta individuação ainda não estava construída, levando a que aquelas comunidades sociais se matizassem com um perfil de governante (que lidera e representa, na sua pessoa, a generalidade global do agregado humano) e governados (constituído pelo próprio corpo social, que atuava e era considerado em conjunto, para fins de direitos e obrigações); tal como, analogicamente, tem-se em uma colméia ou em um formigueiro; culminando com a constatação de que, nesta teia relacional, não havia necessidade ou razão para a aplicação de Direitos Humanos, assim considerados como aqueles comprometidos com o resguardar da dignidade do Homem, estendido a todo e qualquer espécime da humanidade.

Inobstante tal ponderação, faz-se possível uma digressão quanto à gênese dos Direitos Humanos já na Antigüidade, como ramo especializado do nascente Direito, outrora cosmogônico; jungido àquela mencionada e conhecida Escola do Direito Natural. PIOVESAN, aliás, lembrando as palavras de Norberto Bobbio, afirma:

os direitos humanos nascem como direitos naturais universais, desenvolvem-se como direitos positivos particulares (quando cada Constituição incorpora Declarações de Direito), para finalmente encontrarem sua plena realização como direitos positivos universais. ${ }^{19}$

Neste trilhar vislumbrativo, a partir do antigo Direito Natural, o Homem constata que animais da mesma espécie não se matam, e vê, nisto, uma lei cósmica, por isso, universal e eterna, que conclama uma recepção na sociedade humana, a fim de que possa repercutir como virtude edificante da Justiça. Desta intelecção (não isolada ou única, mas aqui traçada de modo exemplificativo), promove-se, entre os Homens, preocupação quanto à preservação da vida humana e construção de um direito à vida - gérmen

\footnotetext{
${ }^{19}$ PIOVESAN, Flávia. Direitos Humanos e o Direito Constitucional Internacional, Max Limonad, São Paulo, 2002, p.124.
}

Revista Brasileira de Direito Internacional, Curitiba, v.6, n.6, jul./dez.2007 
nascente dos Direitos Humanos - com suas conseqüências, que brotam nos séculos seguintes, derivadas das sementes que ali foram plantadas.

\subsection{A CONDIÇÃO DA MULHER NA ANTIGÜIDADE}

Não havendo como se falar da condição individualizada da pessoa humana na Antigüidade, soa como lógica a constatação de que não há como se cogitar de uma condição feminina, passível de tutela e preocupação específica, naquele momento, o que é apenas reflexo incidental de uma condição geral. Isto, porém, não esvazia o propósito do presente artigo, eis que, a preocupação encetada é uma análise da atuação da mulher, nos idos das sociedades antigas.

Apesar de argumentações acerca de sociedades matriarcais préhistóricas ${ }^{20}$, não constam registros oficiais na História, desta vertente social, conquanto, ao revés, as proeminentes civilizações antigas clássicas repercutam, de modo oniabarcante, a existência de sociedades patriarcais, nas quais, às mulheres, eram legadas, em geral, condições de serviência, notadamente em âmbito doméstico.

Seja nas orientais China taoista e Índia hinduísta, ou ocidentais Roma e Grécia, o papel participativo da mulher na sociedade pendia limitado ao ambiente privado, ao tempo em que se reservavam tarefas e atividades sociais públicas, com possibilidades enobrecedoras e dignificantes, aos homens (gênero), que, potencialmente, poderiam desempenhá-las. Curioso, porém, é que a despeito da práxis vivenciada, as diversas teorias cosmogônicas

\footnotetext{
${ }^{20}$ Consta do sítio eletrônico da Revista Galileu: "A possível existência de uma fase matriarcal na história da civilização foi sugerida no século 19 e chegou a ser considerada um fato histórico por importantes arqueólogos e antropólogos até meados do século passado. Ao longo dos últimos 20 anos, porém, houve uma reviravolta no debate, e hoje boa parte da comunidade científica tende a rejeitar a idéia... A hipótese matriarcal surgiu em 1861, quando o suíço Johann Bachofen sugeriu a existência de sociedades matriarcais na pré-história...Em 19010 arqueólogo britânico Sir Arthur Evans descobriu a civilização minóica, que teve seu auge na Grécia entre os século 27 e 11 a.C., e afirmou tratar-se de uma sociedade matriarcal.Para explicar mais exatamente o que isso seria, foram surgindo mais especulações: além da descendência matrilinear, nesses povos as mulheres ocupariam os postos de liderança e até os bens herdados seriam passados de mãe para filha." Disponível in http://revistagalileu.globo.com/EditoraGlobo/componentes/article/edg article print/1,3916,9385 05-1719-3,00.html. Acessado em 31 de outubro de 2007.
}

Revista Brasileira de Direito Internacional, Curitiba, v.6, n.6, jul./dez.2007 
orientais se ocupem em disseminar a perspectiva de que a construção fenomenal se dá com a junção complementar de energias opostas, cuja repercussão material-corporal eclode em gêneros masculino e feminino. Daí a soar a ortodoxia vedantina hinduista que alude, ao lado da potestade masculina SHIVA, a existência de sua contraparte feminina SHAKTI; ou, para fomentar-se outro exemplo, os pólos opostos complementares taoistas do YANG (masculino) e YIN (feminino), que conjunta e conjugadamente dão nascedouro, movimento e termo a tudo que existe. Por esta vertente, diga-se também, que Hermes Trismegisto ${ }^{21}$ - figura emblemática da cultura egípcia antiga, na condição de hierofante, ou, tradutor da verdade cósmica para os Homens (no que aqui se equipara àquilo que o mito grego traduz através do Prometeu), discorre acerca de vários princípios cosmológicos, dentre os quais o do gênero, no momento do vir a ser, movimentar-se e manter-se de tudo o que está manifestado na Natureza.

Direcionando, neste momento, o foco da reflexão à cultura e vivenciar grego clássico, necessário faz-se ressaltar que a cidadania e participação ativa na sociedade somente era conferida aos homens, ou melhor, a alguns homens, àqueles que haviam resolvido as necessidades de sobrevivência e que poderiam dedicar-se à vida, que aqui tem acepção social e pública, excluindose desta possibilidade, dentre outros, escravos e mulheres. Entendia-se, entre os gregos, que somente se poderia ser livre, e vivenciar esta liberdade, no espaço público.

É conhecido, com efeito, o debate acerca da liberdade, no que sugere tal valor para os antigos e para os modernos. Tanto Hannah Arendt como Giorgio Agamben preocupam-se com tal situação, e se a expõe de modo bastante interessante. A propósito, ARENDT, ressaltando o pensamento aristotélico, aduz:

Aristóteles distinguia três modos de vida (bioi) que os homens podiam
escolher livremente, isto é, em inteira independência das necessidades
da vida e das relações dela decorrentes. Esta condição prévia de
liberdade eliminava qualquer modo de vida dedicado basicamente à
sobrevivência do indivíduo - não apenas o labor, que era o modo de
vida do escravo, coagido pela necessidade de permanecer vivo e pela

${ }^{21}$ A etimologia de hermenêutica (interpretação) está vinculada com Hermes.

Revista Brasileira de Direito Internacional, Curitiba, v.6, n.6, jul./dez.2007 
tirania do senhor, mas também a vida de trabalho dos artesãos livres e a vida aquisitiva do mercador. Em uma palavra, excluía todos aqueles que, involuntária ou voluntariamente, permanente ou temporariamente, já não podiam dispor em liberdade dos seus movimentos e ações. Os três modos de vida restantes têm em comum o fato de se ocuparem do $<<$ belo $>>$, isto é, de coisas que não eram necessárias nem meramente úteis: a vida voltada para os prazeres do corpo, no qual o belo é consumido tal como é dado; a vida dedicada aos assuntos da polis, na qual a excelência produz belos feitos; e a vida do filósofo, dedicada à investigação e à contemplação das coisas eternas, cuja beleza perene não pode ser causada pela inferência produtiva do homem nem alterada através do consumo humano. ${ }^{22}$

\section{A explicação arendtiana vai além, agora à vista da manifestação humana no espaço privado e respectiva tônica de liberdade. Vejamos:}

Segundo o pensamento grego, a capacidade humana de organização política não apenas difere mas é diretamente oposta a essa associação natural cujo centro é constituído pela casa (oikia) e pela família. O surgimento da cidade-estado significava que o homem recebera, <<além de sua vida privada, uma espécie de segunda vida, o seu bios politikos. Agora cada cidadão pertence a duas ordens de existência; ${ }^{23}$

Percebendo, distintivamente estes dois segmentos - a vida pública e a vida privada -, conclui ARENDT, à guisa da filosofia aristotélica, explicitando que:

A vida $<<$ boa $>>$, como Aristóteles qualificava a vida do cidadão, era, portanto, não apenas melhor, mas livre de cuidados ou mais nobre que a vida ordinária, mas possuía qualidade inteiramente diferente. Era $<<$ boa $>>$ exatamente porque, tendo dominado as necessidades do mero viver, tendo-se libertado do labor e do trabalho, e tendo superado o anseio inato de sobrevivência comum a todas as criaturas vivas, deixava de ser limitada ao processo biológico da vida. ${ }^{24}$

Partindo destes pressupostos, de seu turno, AGAMBEN afirma, com tenacidade:

Os gregos não possuíam um termo único para exprimir o que nós queremos dizer com a palavra vida. Serviam-se de dois termos, semântica e morfologicamente distintos, ainda que reportáveis a um étimo comum: zoé que exprimia o simples fato de viver comum a

\footnotetext{
${ }^{22}$ ARENDT, Hannah. A condição humana, Rio de Janeiro: Forense Universitária, 2001, p. 2021.

${ }^{23}$ ARENDT, Hannah. A condição humana, Rio de Janeiro: Forense Universitária, 2001, p. 33.

${ }^{24}$ ARENDT, Hannah. A condição humana, Rio de Janeiro: Forense Universitária, 2001, p. 46.
} 
todos os seres vivos (animais, homens ou deuses) e bíos, que indicava a forma ou maneira de viver própria de um indivíduo ou de um grupo. Quando Platão, no Filebo, menciona três gêneros de vida e Aristóteles, na Ethica nicomachea, distringue a vida contemplativa do filósofo (bíos theoreticós) da vida de prazer (bíos apolausticós) e da vida política (bíos políticos), eles jamais poderiam ter empregado o termo zoé (que, significativamente, em grego carece de plural) pelo simples fato de que para ambos não estava em questão de modo algum a simples vida natural, mas uma vida qualificada, um modo particular de vida. ${ }^{25}$

Concluindo que:

A simples vida natural é, porém, excluída, no mundo clássico, da pólis propriamente dita e resta firmemente confinada como mera vida reprodutiva, ao âmbito do ô̂kos. ${ }^{26}$

Percebe-se, pois, haver substancial diferença na acepção da liberdade para os antigos, diante da construção edificada pelos burgueses na modernidade. A liberdade dos antigos era aquela concedida aos gregos que se doavam à polis, e, com sentido de altruísmo entendiam a necessidade do viver participando do espaço público em prol da coletividade, sempre com vistas à realização da virtude. Neste espaço, o cidadão grego - ou, leia-se, alguns homens gregos - efetivamente vivia (daí o vocábulo bio) e se eternizava, legando suas atividades às gerações futuras, contrariamente à idéia de sobrevivência, levada a efeito no espaço privado da oikia, ou, o reino da necessidade (veja-se o vocábulo grego zoe), ao qual a mulher estava confinada.

Apesar desta distinção limitativa à participação da verdadeira vida, em meio à esfera pública, que, como visto, estava reservada a alguns homens, Platão reconhecia na mulher pessoa com mesmos potenciais que os homens. Em A República, o ilustre filósofo aborda e segmenta a humanidade em determinadas classes, em face das funções que se lhes cabem perante a organização social, estabelecendo-as nas seguintes categorias: a) almas de ouro (a quem cabe governar e filosofar); b) almas de prata (aos guerreiros que garantem a defesa da comunidade); c) almas de bronze (comerciantes e

\footnotetext{
${ }^{25}$ AGAMBEN, Giorgio. Homo sacer o poder soberano e a vida nua, Belo Horizonte: Editora UFMG, 2002, p. 09.

${ }^{26}$ AGAMBEN, Giorgio. Homo sacer o poder soberano e a vida nua, Belo Horizonte: Editora UFMG, 2002, p. 10.
} 
artesãos); d) almas de ferro (a quem se destinam as tarefas mais simples). Assim o fazendo, porém, Platão não secciona em gênero masculino-feminino a divisão que ali se dá, vindo, antes, a esclarecer a possibilidade de que uma mulher, detendo alma de ouro, possa ver-se na condição de governar e filosofar, acessando, pois, àquela instância real da vida (bios). Platão, aliás, chegou a receber, em sua Academia, em Atenas, mulheres, a fim de que fossem educadas, tal como os meninos.

Sob viés perspectivo outro, na Antigüidade do Direito Romano, deu-se ensejo à institucionalização do pater familias, ou seja, do poder administrativo das coisas e interesses privados, nos lindes domésticos, em prol do homem, autoridade maior sobre a mulher, filhos e servos; idéia de tamanha força, robustez e disseminação, que impregnou as sociedades futuras, permeada pela via romanística jurídica.

Deste modo, percebe-se que, na Antigüidade, a posição feminina esteve circunscrita aos limites domésticos e ambientes privados (sob domínio diretivo do homem), privada de ascensão ao verdadeiro patamar da vida; muito embora as teorias cosmológicas, aceitas e difundidas, tenham se baseado na complementaridade de gêneros e a perspectiva filosófica platônica tenha aferido uma identidade de possibilidades entre homens e mulheres. Não se olvide, todavia, que referida identidade potencial encontrava respaldo platônico, dada a preconizada responsabilidade pública do Estado, na educação das crianças.

Revista Brasileira de Direito Internacional, Curitiba, v.6, n.6, jul./dez.2007 
3 A EPISTEME JURÍDICA MEDIEVAL ${ }^{27}$. A RUPTURA TEOLÓGICA NA PERCEPÇÃO DOS DIREITOS HUMANOS E A INSERÇÃO SOCIAL DA MULHER NA IDADE MÉDIA

Costuma-se situar o período medieval a partir das invasões bárbaras e da derrocada de Roma, ponto histórico que se percebe partir, aproximadamente de 500 d.C. ${ }^{28}$ Desde então, a episteme antiga vai se desestruturando, principalmente com Justiniano (483 d.C. - 565 d.C.) e a queda do Império Romano. Aquele paradigma cosmológico, que incitava à prática de virtude e construção da Justiça já não mais encontra respaldo, levando, portanto, a que o Direito passasse a assumir outras configurações.

A ruptura epistemológica faz com que o paradigma da Verdade sofra uma alteração do Cosmo para Deus, aspecto que, em si, mantém o Homem (espécie) na dependência de uma inteligência transcendental, muito embora com uma reestruturação do saber, agora resguardado no domínio da divindade. $O$ intérprete oficial desta Verdade encontra-se em meio aos Homens, na Igreja Católica, que castra e rejeita quaisquer conhecimentos pagãos. Não há, pois, que se falar em uma Verdade Cósmica, o que se tem, doravante, é um Deus plasmado à imagem do homem ${ }^{29}$ (gênero), abrindo-se espaço à adoção da episteme teológica.

No período medieval, perde-se a perspectiva de que a Natureza seja perfeita em si e por si, já que, antes, o é segundo o que se lhe é dado pela vontade divina. O mundo medieval, aliás, é resultado da criação divina. Possui sentido, finalidade e projeto, justamente porque decorre da vontade de Deus, que se Ihe aplica à perfeição. Dentro deste contexto, aparece um elemento de finalidade (que é o surgimento do tempo teológico), porém, há um tempo dito escatológico, durante o qual o homem busca sua redenção. Premido pelo

\footnotetext{
${ }^{27}$ A História subdivide o período medieval em Alta Idade Média (aproximadamente de 500 d.C. até 1100 d.C.) e Baixa Idade Média (de 1100 d.C. até 1750 d.C.), sendo que a primeira parte é aquela a que se costuma referir como o período de escuridão, a Idade das Trevas.

${ }^{28} \mathrm{O}$ mundo romano pode ser fracionado em quatro períodos: a) 753 a.C. até 510 d.C. (Monarquia); b) 510 a.C. até 27 d.C. (República); c) 27 d.C. até 285 d.C. (principado ou Alto Império); d) 285 d.C. até 565 d.C. (Dominato ou Baixo Império).

${ }_{29}$ Interessante trazer-se à baila o fato de que o homem medieval constrói a idéia de uma divindade antropomórfica, normalmente associada à figura de um homem de cabelos e longas barbas brancas, tal como Michelangelo (1475-1564) assoberba no teto da Capela Sistina.
}

Revista Brasileira de Direito Internacional, Curitiba, v.6, n.6, jul./dez.2007 
pecado original, o interregno entre criação e fim dos tempos pertence aos Homens, os extremos temporais são de Deus. Aludido momento, assim é exposto por MORRISON:

\begin{abstract}
Não podemos escolher nossos próprios papéis, mas devemos agir sob a direção do diretor/produtor do drama. Um enredo e vários papéis foram criados pelo escritor e pelo diretor; o produtor escolheu pessoas diferentes para o desempenho de diferentes papéis. $\mathrm{O}$ enredo desse drama é fornecido pela inteligência ou razão que impregna todas as entidades, e o cenário é o cosmo. Adquirimos sabedoria ao reconhecermos o papel que nos cabe desempenhar $e$ ao representarmos esse papel da melhor forma possível. Enquanto alguns de nós têm pequenos papéis, a outros cabem os mais importantes, mas todos temos um papel a desempenhar. ${ }^{30}$
\end{abstract}

Diz-se que o Homem medieval até possui uma razão, mas esta tem seus limites no secular e mundano. Já a metafísica está jungida à crença; a essência do ser somente pode ser alcançada pela fé.

O que importa considerar, todavia, é que, para efeito de evolução do Direito, e uma possível ilação quanto aos Direitos Humanos, a Idade Média mais implicou em um retrocesso, à luz do que se pôde produzir através do Direito Romano, principalmente no período de início medieval (Alta Idade Média), quando imperou a irracionalidade e uma assistematicidade, com ensejo de uma confusa pluralidade jurídica31. Os denominados "Juízos de Deus" implicavam na adoção de processos absolutamente irracionais, conhecidos como ordálias, duelos e juramentos ${ }^{32}$.

De qualquer modo, a seqüência temporal medieval (Baixa Idade Média) foi caracterizada pelo aparecimento das primeiras feiras e dos burgos, fomentando um enfraquecimento na fundamentação da Igreja Católica, ao tempo em que o povo começou a perceber que a salvação não dependia, necessariamente, dela, a Igreja. Diante desta novel perspectiva, a aplicação do Direito começa a ser sistematizada por São Tomás de Aquino, que estrutura

\footnotetext{
${ }^{30}$ MORRISON, Wayne. Filosofia do Direito. Dos gregos ao pós-modernismo. São Paulo: Martins Fontes, 2006, p. 61-62.

${ }^{31}$ No período medieval a utilização prática do Direito se fragmentou entre os diversos costumes de cada qual dos povos bárbaros, direito de cada senhor feudal, direito canônico, além de acerbos resquícios do próprio direito romano.

${ }_{32}$ As ordálias sujeitavam o comum do povo; duelos eram destinados aos cavaleiros; juramentos comprometiam a nobreza. $\mathrm{O}$ clero esteve à margem destes processos.
}

Revista Brasileira de Direito Internacional, Curitiba, v.6, n.6, jul./dez.2007 
um trinômio legal, desta maneira: a) lei eterna (a perfeição sem lacunas); b) lei natural (vinculada ao teocentrismo, expressados pelos mandamentos e lições legadas por Jesus, através dos dogmas da igreja); c) lei humana (um reflexo dos fragmentos divinos).

Assim como não se pode aferir uma evolução concreta no Direito Medieval, o mesmo vale para a verificação efetiva que se nos interessa, ou seja, quanto aos Direitos Humanos, isto porque a individualidade do Homem (espécie) permanece inexistente, mas também porque, fundamentalmente, neste momento, não há uma preocupação maior quanto àqueles Direitos Naturais antigos, ao menos não com espeque racional-lógico. Não que o Direito Natural tenha sido abolido, pelo contrário, continuou presente (mas reestruturado), porém sua aplicação era ilógica, fadada a uma ineficácia. A doutrina tomista, diga-se, tenta reedificar o Direito Natural, todavia, quando o faz, distingue direitos do rei, dando vazão ao que, posteriormente, eclodiu como Absolutismo.

Discorrendo-se acerca da evolução histórica dos Direitos Humanos, não se pode furtar, outrossim, à menção do que ocorrido para além da Europa Continental. É preciso distinguir, com efeito, a Grã-Bretanha e o surgir do common law.Já no século XI, Guilherme da Normandia atravessa o Canal da Mancha e submete os Barões ingleses a um único e grande feudo. Henrique II, seu sucessor, contudo, teve que negociar com os Barões, criando tribunais populares em 1166, tendo-se, neste episódio, o adventício do Tribunal do Júri. O giro seqüencial histórico nos retrata a figura de João Sem Terra, que, em 1215 reconheceu a "Magna Carta Libertatum", documento que guarnece importante degrau na construção dos Direitos Humanos, como a joeira dos direitos fundamentais.

Antes de se rematar a presente seção, mister destacar-se que durante todo o período medieval, a mulher sofreu as maiores estigmatizações, sendo mantida à margem da sociedade e tratada como desencadeadora do pecado ${ }^{33}$. A Santa Inquisição se voltou contra muitos, mas teve por foco principal mulheres, levadas à fogueira para expiar os consectários de suas alegadas

\footnotetext{
${ }^{33}$ Consta da gênese cristã que o Homem foi expulso do Paraíso por culpa e responsabilidade de Eva, ao alimentar-se do fruto proibido e cometer o pecado original.
}

Revista Brasileira de Direito Internacional, Curitiba, v.6, n.6, jul./dez.2007 
bruxarias. Inobstante, a instituição do casamento e o estabelecimento da monogamia, em alguma medida, têm significação em prol da condição feminina, a partir da Idade Média, muito embora o sejam mais pela via da submissão ao marido, dado o manter do patriarcado, agora mantido sob todo um instrumental levado a termo com a educação da mulher cristã. 


\section{A EPISTEME JURÍDICA MODERNA. POSITIVAÇÃO DO DIREITO}

\section{NATURAL E A BUSCA DE UMA EFETIVA EMANCIPAÇÃO SOCIAL DA MULHER}

Diz a Antropologia, que o Homem (espécie) é, a um tempo, Natureza e Cultura. Sob tal pressuposto, veja-se que a passagem medieval para a modernidade, se caracteriza por um apartar do Homem em relação à Natureza. Retrata-se, neste momento, uma busca de independência e emancipação humana, que já não está mais à mercê de referenciais cósmicos ou divinos para compreender e acessar a Verdade. Eclode, doravante, a episteme antropológica, fundada na subjetividade do Homem.

Parido da Natureza, o Homem, todavia, carece encontrar meios que respondam à compreensão de seu derredor - plausíveis a este momento, de auto-suficiência -, valendo-se de procedimentos vários, neste afã, inclusive as vias místicas da magia, alquimia, astrologia e cabala, ex vi das heranças legadas desde tempos imemoriais, que, de algum modo, mantinham-se vivas.

Inobstante, Immanuel Kant (possível dignitário do epíteto de Pai da Modernidade), publica, em 1794, ensaio intitulado "O que é o esclarecimento?". Percebendo as relações racionais e todas as revoluções que, à época, ocorriam com o surgimento das ciências, Kant indaga-se quanto em que consiste o esclarecimento, dando, assim, nascimento à modernidade, aventando sobre a saída da menoridade do Homem (outrora dependente, seja do Cosmo ou de Deus) para sua maioridade auto-centrada e edificadora da independência. Qual em rito de passagem, analogicamente, Kant descreve a necessidade de que o Homem saia da dependência do mundo para encontrar em si a emancipação. Referido texto revoluciona a filosofia e dá ensejo às ciências humanas ${ }^{34}$.

\footnotetext{
${ }^{34}$ Segundo Antônio Rogério da Silva: "Os motivos que levaram Kant a escrever "O Que é Esclarecimento?" estão relacionados à mesma questão proposta pelo jovem teólogo Johann Friedrich Zöllner (1753-1804) que se manifestou com irritação contra uma proposta anônima, que surgiu em meados de 1783, para abolição do casamento religioso. Kant levou a sério o questionamento desse pastor, lançado na revista Berlinische Monatsschrift, de setembro de 1783, e preparou a sua resposta que foi publicada no mesmo periódico em dezembro de 1784. $\mathrm{E}$, logo no início, Kant abre com um primeiro parágrafo que faria jus a qualquer manifesto do movimento, caso o iluminismo tivesse necessitado de uma formulação tão precisa quanto esta:
}

Revista Brasileira de Direito Internacional, Curitiba, v.6, n.6, jul./dez.2007 
Kant debate a possibilidade de serem encontrados critérios apodíticos, ou seja, conhecimentos necessários, criticando tanto os resultados de escolas filosóficas empíricas, como também as escolas racionalistas. Busca a possibilidade de alcançar conhecimentos necessários (e não acidentais), fazendo uma mediação entre os céticos empiristas e os dogmáticos racionalistas. MORRISON discorre a este respeito:

as florescentes ciências empíricas pareciam oferecer o verdadeiro conhecimento; contudo, elas próprias assentavam-se sobre bases não racionais. Ao longo de sua formação, Kant fora levado a acreditar na razão e a esperar que, mediante o uso da razão, os homens conheceriam os deveres que deles se esperavam e saberiam o que era certo fazer na vida. ${ }^{35}$

A partir da filosofia kantiana, delimita-se a área de utilização da razão humana para o campo do fenomênico, passível de ser tateado através da ciência, abandonando-se, doravante, sendas místicas no propósito de alcance do saber.

\subsection{O ECLODIR DOS DIREITOS HUMANOS E SUA EVOLUÇÃO DURANTE A MODERNIDADE}

No âmbito político-econômico, a estruturação da sociedade converte-se de um milenar sistema feudal para um sistema estatal soberano que, após a experiência absolutista, pôde albergar o adventício do capitalismo, na moldura inicial do Estado Liberal. Do Absolutismo ao Estado Liberal, diga-se, a vivência humana produziu a construção do constitucionalismo, coroando a positivação dos Direitos Humanos, em cercos territoriais de determinados Estados.

\footnotetext{
"Esclarecimento é a saída do homem de sua menoridade, da qual ele próprio é culpado. A menoridade é a incapacidade de fazer uso de seu entendimento sem a direção de outro indivíduo. O homem é o próprio culpado dessa menoridade se a causa dela não se encontra na falta de entendimento, mas na falta de decisão e coragem de servi-se de si mesmo sem a direção de outrem. Sapere aude! [Ousar saber] Tem coragem de fazer uso de teu próprio entendimento, tal é o lema do esclarecimento" (KANT, I. "Resposta à Pergunta: Que é 'Esclarecimento'", p. 100), disponível http://br.geocities.com/discursus/moderna/oquescla.html. Acessado em 28.10.2007. ${ }_{35}$ MORRISON, Wayne. Filosofia do Direito. Dos gregos ao pós-modernismo. São Paulo: Martins Fontes, 2006, p. 156.
} 
De se consagrar, neste momento, a erupção histórica dos Direitos Humanos; ora, metodologicamente, expressados sob a alcunha de primeira geração ${ }^{36}$. Aludidos direitos estão diretamente associados ao eclodir do Estado Liberal, estruturado sob a égide constitucional que confere aos Homens uma proteção quanto aos possíveis desmandos estatais. Aqui se encontram os precípuos Direitos Naturais da Antigüidade, notadamente o direito à vida, como também o direito à segurança e à propriedade, conferidos e legalizados através das primeiras constituições que mundo presenciou, a norte-americana (de 1787) e a francesa (de 1791), ambas de tônica liberal.

O manejo de novas tecnologias possibilitou ao Homem ascender à denominada Revolução Industrial ${ }^{37}$, que, como conseqüência, deu ensejo a uma produção em alta escala, muito embora o esforço laboral de homens e mulheres tenha sido importante peça do maquinário fabril. A ausência de regras, no que diz respeito, aos limites quanto ao trabalho e pessoas susceptíveis de executá-lo, aliado à existência de uma classe deveras enriquecida (os burgueses) - sem nenhum controle de distribuição de renda (temática central do liberalismo) -, são argumentos que compõem o mosaico de uma grave crise social, que ganhou o mundo na virada do século $X X$, exarando, à superfície, duas guerras mundiais e uma crise geral dos mercados, com a quebra da bolsa de Nova lorque, em 1929.

Este fúnebre cenário engendra o irromper de uma nova gama de Direitos Humanos - naquela mencionada metodologia, cunhados como de segunda geração -, voltados à construção de um mercado consumidor, que

\footnotetext{
${ }^{36}$ À míngua das plausíveis críticas expressadas em razão do referir-se geracional aos Direitos Humanos, a apresentação dos mesmos, assim postada, é de uma didática deveras interessante, no exercício de sua compreensão do tema, valendo, pois, o cunhar procedido por Karel Vasak, neste pormenor. A respeito, aponta Flávia Piovesan: "Assim, partindo-se do critério metodológico que classifica os direitos humanos em gerações, compartilha-se do entendimento de que uma geração de direitos não substitui a outra, mas com ela interage. Isto é, afasta-se a equivocada idéia da sucessão "geracional" de direitos, na medida em que se acolhe a idéia da expansão, cumulação e fortalecimento dos direitos humanos, todos essencialmente complementares e em constante dinâmica de interação." PIOVESAN, Flávia. Direitos Humanos e o Direito Constitucional Internacional, Max Limonad, São Paulo, 2002, p.149-150.

37 Considera-se o início da Revolução Industrial na Inglaterra, durante o século XVIII, caracterizando, tal momento histórico pela suplantação de uma economia agrícola com uma atuação industrial; alcançando-se uma produção em massa, com a utilização de maquinários, para além da força humana.
}

Revista Brasileira de Direito Internacional, Curitiba, v.6, n.6, jul./dez.2007 
pudesse reerguer a sociedade capitalista. Aporta-se ao Welfare State, ao denominado Estado Providência, que, além das garantias fundamentais outrora reconhecidas, provê necessidades humanas outras, como educação, saúde e previdência social, possibilitando, por via reflexa, o estipêndio salarial a ser destinado ao consumo dos bens produzidos no capitalismo. Aludida vertente estatal se legaliza através de novas formatações constitucionais, das quais se alude àquela mexicana de 1917 e alemã, de Weimar, de 1919.

Pari passu à chancela dos direitos fundamentais estatizados, desenvolve-se todo um instrumental focado na internacionalização destes direitos, mirados à dignidade do Homem (que, entende-se, deve ganhar o mundo), ex vi dos vórtices de civilidade alcançados no Ocidente desenvolvido. Referido procedimento se dá através das Relações Internacionais e com a criação de Organizações Internacionais comprometidas com determinados assuntos de interesses gerais e específicos. Neste afã, de se ressaltar, sobretudo, a criação da Organização Internacional do Trabalho (OIT), que, atenta àquelas barbáries e excessos da Revolução Industrial, disseminou uma cultura jurídica voltada à limitação das possibilidades industriais, com respeito a um mínimo de direito dos trabalhadores, especialmente àqueles mais vulneráveis, como crianças e mulheres; como também à própria Organização das Nações Unidas (ONU), que, quando de seu surgimento, no pós Segunda Guerra Mundial, em substituição à Liga das Nações, em 1945, o faz com forte comprometimento na internacionalização dos Direitos Humanos, seja em razão do teor embutido em sua carta constitutiva ${ }^{38}$, seja, principalmente, com a adoção da Declaração Universal dos Direitos Humanos, em 1948.

O surgimento de um novo modelo estatal vem se fazendo sentir desde os anos oitenta, do século XX. Os efeitos referentes à globalização econômica, alcance de mercados em nível mundial, e, sobretudo, consolidação daquele projeto anterior de reestruturação do sistema, conclamam à dissociação dos

\footnotetext{
${ }^{38}$ Assevera Flávia Piovesan: "A Carta das Nações Unidas de 1945 consolida, assim, o movimento de internacionalização dos direitos humanos, a partir do consenso de Estados que elevam a promoção desses direitos a propósito e finalidade das Nações Unidas. Definitivamente, a relação de um Estado com seus nacionais passa a ser uma problemática internacional, objeto de instituições internacionais e do Direito internacional." PIOVESAN, Flávia. Direitos Humanos e o Direito Constitucional Internacional, Max Limonad, São Paulo, 2002, p.142-143.
}

Revista Brasileira de Direito Internacional, Curitiba, v.6, n.6, jul./dez.2007 
comprometimentos do Estado de Bem-estar Social e a efetivação de um novel liberalismo, ao que se procede através do que hoje se denomina o Estado Neoliberal. Não que esta roupagem seja, per se, constitutiva de uma outra ordem de Direitos Humanos, mas é mote, através dos efeitos (almejados) de uma mundialização, da construção de um manancial diverso - aludido como Direitos Humanos de terceira geração -, ora albergando preceitos coletivos de paz, progresso, autodeterminação dos povos, desenvolvimento, com respeito a um meio ambiente equilibrado.

À guisa da presente exposição, de modo panorâmico, vê-se a evolução não só da episteme jurídica na modernidade, calçada na subjetividade do Homem, o que, por si, tornou tangível o aparecimento e desenvolvimento dos Direitos Humanos, segundo as necessidades e tônicas temporais que perpassam a história da humanidade. Importa considerar, todavia, a condição feminina dentro desta efervescência.

\subsection{A ESPECIAL PROTEÇÃO DOS DIREITOS HUMANOS EM FACE DA MULHER E A CONDIÇÃO FEMININA NA MODERNIDADE}

A positivação constitucional do Direito Natural, espraiada à internacionalização dos Direitos Humanos conferiu um especial regime de proteção à mulher, para além do regime geral adotado pela International Bill of Rights $^{39}$, adunando, dentre outros, um enfoque voltado à proteção feminina, fulcrado na Convenção sobre a Eliminação de todas as formas de Discriminação contra a Mulher (aprovada pelas Nações Unidas em 1979), e no respectivo Protocolo Opcional que institui um Comitê para receber denúncias afetas a violações contra os direitos da mulher (aprovado em 1999); tudo com o propósito explícito de eliminar a discriminação sofrida pelo gênero feminino e assegurar uma igualdade jurídica entre homens e mulheres.

\footnotetext{
${ }^{39}$ Flávia Piovesan ressalta que a International Bill of Rights, ou, Carta Internacional de Direitos Humanos é "integrada pela Declaração Universal de 1948 e pelos Pactos Internacionais de 1966". PIOVESAN, Flávia. Direitos Humanos e o Direito Constitucional Internacional, Max Limonad, São Paulo, 2002, p.164.
}

Revista Brasileira de Direito Internacional, Curitiba, v.6, n.6, jul./dez.2007 
Como antes asseverado, é deveras importante e nobre, o objetivar desta proteção, já que, historicamente, a mulher pendeu relegada a plano de somenos importância, sofrendo, no mais, agressões físicas, morais e psicológicas, em quadro que se robusteceu no curso da modernidade, sobretudo em razão de um mal versar do poder que emana das camadas dominantes da sociedade (vide os efeitos reflexos da Revolução Industrial quanto à mulher), em face da existente e mantida sociedade patriarcal. Ao lado desta barreira protetiva, ecoam, no entanto, efeitos contigentes quanto àquele discurso de igualdade $^{40}$, corroborando ao aprofundar da causa feminina e concorrendo para que a mulher passe a assumir responsabilidades que se the são novas no contexto social.

A individualização do Homem (espécie) moderno implica, necessariamente, na individualização pessoal de cada homem (gênero) e mulher, o que, por corolário, leva à emancipação humana e, por extensão, feminina. Esta emancipação, no entanto, não é algo já conquistado, senão ideal construído no viver diário; ideal, diga-se, que vai para além da condição de gênero, acometendo a espécie como um todo. Sucede que a construção desta emancipação feminina encontrou forte resistência social, fomentando a ocupação protetiva da mulher.

Enfocando-se os denominados direitos civis e políticos, quais sejam, aqueles antes aventados como de primeira geração, forçoso reconhecer-se que à mulher, referidos direitos não acorreram, tampouco foram efetivados em mesmo momento que ao homem. Somente no final do século XIX, na Inglaterra (que, como que modelarmente, passa a inspirar tais efeitos ao orbe terrestre), é que o dito sufrágio universal espraiou-se para o gênero feminino, tornando-se assim verdadeiramente universal. Esta brecha permite às mulheres não só participar da vida cívica e da esfera pública, expressando suas opiniões particulares, como também a se submeterem a cargos públicos, resultando, hoje, na mais do que evidenciada vida ativa das mulheres em meio às

\footnotetext{
${ }^{40} \mathrm{O}$ artigo 5ำ, alínea "a", in fine, da Convenção sobre a Eliminação de todas as formas de Discriminação contra a Mulher, propugna a adoção a medidas apropriadas para modificar padrões sócio-culturais de condutas masculinas e femininas tendentes à discriminação e preconceito baseados em funções estereotipadas de homens e mulheres.
}

Revista Brasileira de Direito Internacional, Curitiba, v.6, n.6, jul./dez.2007 
sociedades na quais se encontram, e mesmo na sociedade internacional, gerando com isso, como que reflexamente, uma conseqüência de incompreensão quanto à condição feminina (historicamente adstrita ao lar e à educação das crianças, no âmbito privado da oikia, ou da família, como alhures ressaltado) e o papel cabível ao homem, que ora se vê premido no espaço público, conjuntamente com a mulher, que, competentemente, mostra-se capaz de ali fazer-se presente.

Ocorre que os choques civilizatórios e as harmonias sociais estabeleceram uma busca de compreensão quanto à respectiva individualização do Homem, que, nas diferenças, pôde se entender enquanto ser consciente e racional, opondo-se, assim, à Natureza e ao outro. Quando diz-se diferenças, fala-se de toda a construção subjetiva do Homem, aqui cabendo uma aporia. Em que pese a preocupação dos Direitos Humanos na construção de uma igualdade jurídica entre homens e mulheres, as diferenças de fato (decorrentes mesmo das dessemelhanças anatômicas e fisiológicas) influem, de algum modo, na subjetividade de cada ser humano. Interessante refletir-se que uma via de evolução do Direito é buscar uma equivalência daquilo que já consta na esfera da sociedade. Igualdades de fato pressionam a que desigualdades jurídicas sejam suplantadas. O que ocorre in casu, porém, é um exercício por via inversa, ou seja, desigualdades sociais estão sendo suplantadas por um discurso de igualdade jurídica; o que, evidentemente, gera conseqüências no conviver social, muito embora a capacidade de quaisquer dos gêneros (homem e mulher) seja a mesma para a assunção de papéis em âmbito social ou doméstico.

De se refletir, todavia, concita-se, quanto à possível existência de desigualdades efetivas na vocação feminina ou masculina, sem que nisso se recaia em um vulgar estereotipar da condição do homem e da mulher, com visos à discriminação e à violência. A formação física, emocional e psicológica da mulher comporta um conjunto diferenciado da formação masculina, provendo, cada qual, de facilidades em determinadas áreas de atuação, sem que isso signifique exclusividades, tampouco retire a potencialidade para execução de quaisquer coisas. O que um Homem (espécie) pode fazer, 
qualquer outro tem, em potência, ainda que latente, a capacidade, inobstante maiores ou menores dificuldades para tanto, inobstante as aptidões naturais, próprias de cada qual.

O vislumbrar atual da sociedade internacional nos brinda com a percepção de que o valor de inúmeras mulheres e o comprometimento com a causa feminina içou-as a patamares antes inatingíveis, nas esferas da política, filosofia, artes, economia, esporte, ciências, etc. (fazendo, inclusive, com que o vernáculo das diversas línguas do globo passem a sofrer adaptações, para comportar o exercício de atividades por mulheres em presidências, embaixadas e outras áreas ${ }^{41}$ ); muito embora ainda perdurem alguns bastiões da masculinidade, afetos à religião ${ }^{42}$. Em contrapartida, faz-se inegável a crise de valores que permeia o viver humano, acometendo dificuldades assaz insólitas no exercício de auto-compreensão do Homem.

Ponto crucial, a delimitar um momento da construção desta emancipação feminina diz respeito à tecnologia que possibilitou a utilização da pílula anticoncepcional, que, assim disponibilizada, torna-se instrumento (não à capacitação) ao encorajamento do mulher na ascensão de outros patamares sociais. Nada obstante, crianças continuam sendo geradas aos milhões, sem que a sociedade humana se mostre estabelecida e centrada em bases harmônicas, no que toca à criação e educação destes indivíduos, nascidos sob a égide de um momento confuso quanto à participação de homens e mulheres em uma construção saudável da realidade.

Atento a esta questão, o psicanalista belga Jean-Pierre Lebrun, destaca a necessidade de que a criança perceba diferenças no entorno, especialmente que digam respeito ao papel de pai e mãe, ou, em largas sociais, do homem e da mulher, sob risco de ver sepultada a construção de sua própria subjetividade, fatalizando à criança, o ser engolido por um sistema de

\footnotetext{
${ }^{41}$ Questiona-se, por exemplo, em língua portuguesa, a adoção e utilização da palavra "presidenta" ou adoção de "presidente" para ambos os gêneros humanos. Em italiano surge a palavra "avvocatessa", que, até determinado época era profissão limitada aos "avvocatos", operadores do Direito, ou, advogados em português.

${ }^{42}$ Seja nas grandes religiões ocidentais (cristianismo e judaísmo), ou nas orientais (budismo, hinduismo, islamismo), percebe-se uma dominante presença masculina nas esferas de comando dos rituais e dogmas. As portas do poder eclesiástico ainda estão vedadas às mulheres.
} 
cunho totalitário, fincado em um discurso de igualdade absoluta, inobstante a desigualdade fática. Lebrun menciona que tudo que existe, existe em relação ao seu contrário. Neste sentido, a diferença entre bem e mal, positivo e negativo, não tem como ser eliminada. A questão é encontrar-se um ponto ético de diferenciação, que ecoa como necessária no que toca ao gênero humano e sua complementaridade.

Seja o exercício de poder pelo homem, seja o que ora é podido ser exercido pela mulher, falta, percebe-se, uma noção de unidade e complementaridade, a partir das saudáveis diferenças (não só de gêneros, mas até de individualidades), que conjugada e fraternamente, podem levar a uma construção emancipatória do Homem.

A presente discussão, crê-se, não tem e não terá fim enquanto não houver uma verdadeira compreensão quanto ao sentido e significado dos Direitos Humanos, com norte motriz de responsabilidade, concorrente, do indivíduo pelo coletivo. 


\section{CONSIDERAÇÕES FINAIS}

À luz de uma análise quanto à participação social da mulher no correr histórico da humanidade e sua ativa atuação no mundo ora presente, segundo as sistemáticas alterações epistemológicas do Direito, notadamente ex vi do que hoje se tem por Direitos Humanos, percebe-se que, além da necessária proteção especial, direcionada pela sociedade internacional ao gênero feminino, deu-se um desencadear de crise quanto à compreensão subjetiva do ser humano, fruto, senão de outros motes instrumentais diversos, do gradual evolver emancipatório da mulher e a assunção de atividades que se the eram estranhas; sem que se perceba nisto, uma preocupação em construir-se uma evolução humana. A busca de emancipação feminina, per se, acaba por demonstrar uma afirmação de diferenças em relação ao gênero masculino, do qual se pretende uma independência. Antes, a busca toda deveria ser de uma emancipação do Homem (espécie), com uma compreensão clara de distinções e complementaridades de gêneros.

Inobstante aludidas considerações, não se pretende aqui - deveras longe disso - apresentar-se quaisquer conclusões, até porque se percebe uma premente necessidade de um aprofundar-se no tema, valendo-se de aportes teóricos interdisciplinares, notadamente filosóficos e psicológicos.

Ficam aqui, de qualquer modo, estas linhas, na modesta expectativa de que a apresentação do tema possa fomentar sérias e amadurecidas reflexões, voltadas à construção de uma sociedade plural, assentada em bases éticas, com igualdades de oportunidade, apesar das diferenças circunstanciais que caracterizam e impregnam qualquer ser humano, sem que se abdique de uma consciência coletiva, quanto à responsabilidade conjunta dos Homens no preencher de todas as necessidades sociais.

Revista Brasileira de Direito Internacional, Curitiba, v.6, n.6, jul./dez.2007 


\section{REFERÊNCIAS}

AGAMBEN, Giorgio. Homo sacer o poder soberano e a vida nua. Belo Horizonte: Editora UFMG, 2002.

AQUINO, São Tomás de. Vida e obra. São Paulo: Nova Cultural, 1996.

ARENDT, Hannah. A condição humana. Rio de Janeiro: Forense Universitária, 2001.

BALZAC, Honoré de. A mulher de trinta anos. São Paulo: Martin Claret, 2002.

BARRETTO, Vicente de Paulo (coordenador). Dicionário de Filosofia do Direito. Rio de Janeiro: Renovar, 2006.

CíCERO, Marco Túlio. As catilinárias. São Paulo: Martin Claret, 2006.

JAEGER, Werner. PAIDÉIA: a formação do homem grego. São Paulo: Martins Fontes, 2001.

KANT, Immanuel. Crítica da razão pura. São Paulo: Nova Cultural, 1996.

LEBRUN, Jean-Pierre. Um mundo sem limite. Rio de Janeiro: Cia de Freud, 2004.

MORRISON, Wayne. Filosofia do Direito. Dos gregos ao pós-modernismo: São Paulo: Martins Fontes, 2006.

NIETZSCHE, Friedrich. Assim Falou Zaratustra. São Paulo: Martin Claret, 2005.

PIOVESAN, Flávia. Direitos Humanos e o Direito Constitucional Internacional. São Paulo: Max Limonad, 2002.

PLATÃO. A República. São Paulo: Nova Cultural, 1996.

ORGANIZAÇÃO DAS NAÇÕES UNIDAS. Resolução $n$. `3275. Disponível em: http://daccessdds.un.org/doc/RESOLUTION/GEN/NR0/743/54/IMG/NR074354. pdf?OpenElement. Acesso em 30 de outubro de 2007.

PREFEITURA MUNICIPAL DE SÃO PAULO. O dia internacional da mulher. Disponível:http://www.prefeitura.sp.gov.br/portal/a_cidade/noticias/index.p $h p ? p=1195$. Acessado em 30 de outubro de 2007.

REVISTA GALILEU. A sociedade matriarcal na pré-história. Disponível em:http://revistagalileu.globo.com/EditoraGlobo/componentes/article/edg_articl e_print/1,3916,938505-1719-3,00.html. Acessado em 31 de outubro de 2007. 
SHAKESPEARE, William. Hamlet. São Paulo: Martin Claret, 2000.

SILVA, Antonio Rogério. Os motivos que levaram Kant a escrever O que é o esclarecimento?. Disponível em

http://br.geocities.com/discursus/moderna/oquescla.html. Acessado em 28.10.2007.

SÓFOCLES. Antígona. Brasília: UNB, 1997.

VIEIRA, Claudinei. Honoré de Balzac. Disponível em:

http://igeducacao.ig.com.br/igler/materias/207501-

208000/207784/207784_1.html. Acesso em 30 de outubro de 2007.

Revista Brasileira de Direito Internacional, Curitiba, v.6, n.6, jul./dez.2007 